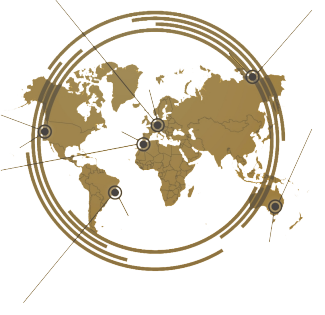

\title{
Promoting Students' Autonomous Learning Using Portfolio Assessment in EFL Writing Class
}

\author{
Peptia Asrining Tyas* \\ English Education Program, Faculty of Cultural Studies, Universitas Brawijaya, Malang, Indonesia
}

This study attempts to present the implementation of portfolio assessment to promote students' autonomous learning in one of reputable universities in Indonesia. The participants were 30 students enrolled Essay Writing Class. A collection of students' work during the course in the form of 'Essay Writing Module' was used to provide authentic evidence of the implementation of portfolio assessment and observation checklists of students' work was used to present the completeness of portfolio assessment of each student. To know students' autonomous learning, semi-structured interview was carried out. The results prove that portfolio assessment can promote students autonomous learning since it provides some benefits for students such as motivate them to do selfevaluation and reflection, encourage them to be actively involved in peer review session, and also enhance their awareness of their weaknesses.

Keywords: portfolio assessment, students' autonomous learning, EFL

\section{INTRODUCTION}

Studies on portfolio assessment as teaching and learning tools for developing academic writing have been done in recent years, yet the discussion only focus on the portfolios process as in Ilke Büyükduman and Şirin (2010); Chang et al. (2013) and focus on students' attitudes and perceptions about the portfolio process as in Aydin (2010) and Lam (2013). Thus, the writer proposes portfolio assessment to be used in essay writing classroom by emphasizing the discussion on both the writing process assessment and product assessment in order to promote students' autonomous learning by engaging students in assessing their on-going learning and provide them clear idea of how the lecturer will evaluate their work including the criteria used in giving score.

As stated by Widodo (2008) there are two perspectives of teaching writing. The first is cognitive perspective. In this perspective, writing should be taught as a process of forming concept and ideas for certain purpose, audience, and language use. Thus, the process of writing involves some activities that are done recursively. They are pre-writing, drafting, revising, and editing. The second is humanistic perspective. In humanistic, writing is used as a medium to explore and discover meaning. From those two perspectives, it can be seen that EFL lecturers should not only emphasize on the writing process that encourages students to be actively involved in and out activities of writing class, but also emphasize the students' writing product which focuses on the students' grammatical and lexical accuracy to outgrow cohesion and coherent of the product. Thus, it can promote students' autonomous learning in which they have to be responsible for their learning. They need to take control for their learning including the needs, goals, selfdoi: 10.21070/jees.v5i1.379 
assessment as well as peer-assessment to complete their work. In autonomous learning students should be able to setting their own goal, planning the activities to achieve the goals including finding their own learning resources, and also assessing their own progress (Ilke Büyükduman and Şirin, 2010; Ceylan, 2015; Chan, 2003; Railton and Watson, 2005). However, in reality it cannot be implemented directly in the classroom since every classroom course has a certain learning goal based on the curriculum. Therefore, students' autonomous learning in this current study was fostered by communicating the learning with the students in which reflected through the implementation of portfolio assessment.

There are 6 stages in implementing portfolio assessment; introducing the ideas of portfolio assessment, establishing the purpose of portfolio assessment, specifying the contents, setting the assessment criteria, establishing the mastery standard and the last is organizing portfolio conference. Further, the students' score in writing will be taken from the completeness of their portfolio assessment and also score from their final products.

\section{The essential elements of portfolio assessment in writing}

Sample of students work, students self-assessment, and clearly stated criteria becomes the essential elements of Portfolios Assessment (O'malley and Pierce, 1996). Sample of student work depends on students and teacher preferences as well as its purpose based on instructional goals in which provide clear vision on the students' improvement over time. Students SelfAssessment is also an important part of portfolio. It gives students chance to learn and to take control of their own improvement and progress so that they can be responsible for their effort on how to reach the learning goals set both by students and teacher. Another essential element of Portfolio assessment is Clearly Stated Criteria which provides criteria and standard to evaluate the completeness as well as the quality of the students' sample work. In this case, the teacher should involve students in setting the criteria and standard used.

\section{Implementing portfolio assessment in writing Instruction}

In this research, the writer proposed seven stages in implementing Portfolio assessment in essay writing instruction by combining writing stages from three experts (Brown, 2007; Richards and Renandya, 2002; Widodo, 2008). The writing adopts planning and drafting stages proposed by (Richards and Renandya, 2002) because in the planning the students will focus on generating ideas and organizing ideas; while drafting promotes the fluency of ideas. The peer-review stage is adopted from Brown (2007) since it can be used in encouraging students to participate actively in the class, involving them in an authentic communicative context, and developing stu- dents' critical reading skill by using scoring guide. The rest of the stages (responding, revising and editing, assessing, postwriting, and reflection) taken from Widodo (2008). Thus, the following stages will be used in this present study for writing instruction.

\section{Planning}

this stage is suitable in stimulating students' ideas or thoughts to get started in their writing and helping the students to organize and develop their ideas into completed essays. There are two steps in pre-writing activity. First is generating ideas and the second is organizing ideas. Based on Boardman and Frydenberg (2002), generating ideas is an activity that can be used to think about a certain topic and generate as many ideas as possible. There are many ways to generating ideas, such as brainstorming, free writing, clustering, and wh-questions. While organizing ideas concerns with the method used to help students to organize ideas. It can be done by outlining or making tree diagram.

\section{Drafting}

It focuses on the fluency of writing or promotes the fluency of ideas. In this stage, the teacher should disregard the grammatical accuracy.

\section{Peer-review}

This activity is used in encouraging students to participate actively in the class, involving them in an authentic communicative context, and developing students' critical reading skill by giving feedback on their peer using scoring guide that covers content, organization, mechanics, vocabulary, and grammar.

\section{Revising and Editing}

The aim of these stages are to produce well-written essays. Here, the teacher also provides feedback for students' work. Thus, in the revising activity, the students review their own work based on the feedback given in the previous stage. They have to look at not only on the language errors but also the content and the organization of ideas. While in editing, students are expected to check the minor mistakes in relation with grammar, spelling, punctuation, diction, and contraction (O'malley and Pierce, 1996).

\section{Assessing}

(a) Process assessment: ongoing assessment used to see the completeness of students' work during the course by using checklist. (b) Product assessment: the teacher gives scores on the students' work by using scoring rubric to examine how well each student or each group has completed the work. This product assessment will be given after some practices or when the teacher believes that the students have the ability to write an effective essay. The suitable scoring or grading for process- 
based essays writing instruction is by using analytical scoring system because it allows students to look at their weaknesses on the particular aspects.

\section{Post-writing}

It deals with the activities that are used to appreciate students' work in relation with the completed essays. It may cover publishing online or displaying the finished essays on notice boards, sharing with one another, or reading aloud.

\section{Reflection}

The purpose of reflection here is to encourage students to reflect on what they have learned during the writing process. Hopefully, they can promote their awareness of writing practice.

The process-based in this academic essay writing instruction involves various stages which intended to guide the teacher to take the best steps for writing activities in the classroom to have the best route in helping the students to reach the goal.

\section{Portfolio assessment for autonomous learners}

Portfolio assessment is a purposeful and systematic collection of students' work that is intended to show progress over time (Nicolaidou, 2013; O'malley and Pierce, 1996; Yastibas and Yastibas, 2015; Lam, 2013). Portfolio assessment usually contains of selected students' work that can be used to represent their learning based on the instructional objectives. In addition, Portfolio assessment also focuses on collection of students' work during writing process that reflected certain learning goals systematically, which includes writing process checklist, self-assessment sheet, drafts of writing with teacher's feedback, and the final product (Aydin, 2010; Ilke Büyükduman and Şirin, 2010; Romova and Andrew, 2011). Further, the students' portfolio will be evaluated on specific criteria by both students and English teacher.

It is enlightened then that portfolio assessment not only can provide students with an opportunity to do reflection or selfevaluation about their learning and writing performance of a certain task but also give them a medium to show their authentic language use. With systematic artifacts including the drafts of essays documented, portfolio assessment envisions the students about their engagement on their own learning. It is in line with a research result conducted by Romova and Andrew (2011). The result showed that a multiple draft of students work can be used as an effective assessment tool, not merely because it gives students a series of feedback but also because it improves their understanding of writing as a continuous process. It also found that portfolio assessment can develop some aspect of writing competence such as self -editing and encourage the students to apply target genre and discourse competence in organizing academic texts.
In addition, by using Portfolio Assessment, students were motivated to be self-assessors of their own development in writing (Khonbi and Sadeghi, 2012). They also said that the learners not only focus on their previous ability or performance but also set goals to improve their writing competence. It means that the students became more aware on the importance of self-reflection and autonomy learning through self-evaluation activities during completing their portfolio assessment.

Further, a previous research result conducted by Sundeen (2014) showed that scoring rubrics becomes a tool to ease the writing process and evaluate students' work effectively. If the students understand well what criteria used to evaluate their work, they will also understand what the lecturer expected from them so that their writing competence can improve. At the same time, by using scoring rubric, students can be able to practice judging their writing quality. As a result, they will be able to identify their own strengths and weaknesses. It is in line with Nicolaidou (2013); Wang (2014) who state that students often do not know the specifics of what we are looking for as teachers, but by providing scoring guide, such confusion can be avoided. Therefore, by using portfolio assessment, it was proved that by engaging students directly in the assessment process will help students to learn writing autonomously.

In Indonesian EFL context, there is limited number of research concerning the use of portfolio assessment as media to enhance students' engagement in teaching and learning process by promoting learners autonomy. Most of the previous researches focus on how to improve students' achievement through portfolio assessment. Considering this reason, in this current research, the researcher examines the use of portfolio assessment in enhancing students' autonomous learning by formulating the following research problems: How does portfolio assessment enhance students' autonomous learning in EFL Essay Writing Course?

\section{METHOD}

This research used classroom action research. A sample of 30 undergraduate students majoring English Department were the participants in this study. The students were in their third semester. They had Essay Writing class which focused on writing several expository text type covering cause-effect, comparecontrast, and problem solution. This research was done on the second half of the semester focusing on writing cause-effect and problem solution expository text.

In this current study, the researcher only conducted 1 cycle (see Figure 1) in completing the data. Before conducting the cycle, the first stage in this research was preliminary study to observe the problem faced by the students during the first half of the semester in Essay Writing class. Before taking this course, the students need to pass paragraph writing course and not all students came from the researcher's classes in which students will be evaluated based on the process, product, and student's effort in completing the task. Although at the beginning of the 
course the researcher explained how their work will be evaluated (both process and product), most of them still ignored the process. Only $20 \%$ or 6 students, out of 30 students, do peerreview well by showing their understanding, comment, and suggestion towards their peer's draft. Moreover, only $60 \%$ or 18 students, out of 30 students, do face-to-face consultation with the lecturer in developing their outline. It also found that not all students actively involved in group discussion when they have to work in group. Therefore, the result of this preliminary study becomes the basic consideration to set up planning, implementation, observation, and reflection as depicted in Figure 1

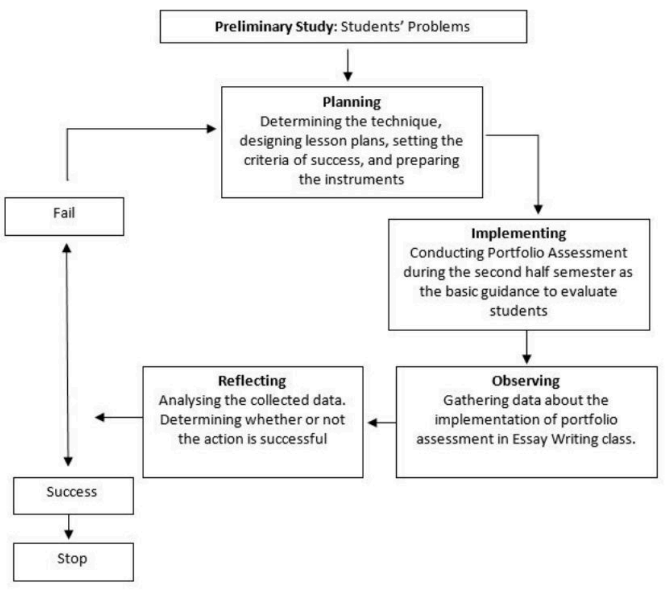

FIGURE 1 | The design of the study

In collecting data, a collection of students' work during the courses in the form of 'Essay Writing Module' is used to provide authentic evidence of the implementation of portfolio assessment and observation checklists of students' work is used to present the completeness of portfolio assessment for each student. The process of portfolio assessment is described in Figure 2.

To know students' autonomous learning, observation checklist (see Table 1) and semi structured interview guide (see Appendix ) were used in this current study. The researcher set $80 \%$ of student engage in the classroom activities as the criteria of success.

\section{RESULTS AND DISCUSSION}

The research result shows that after the action, the students' engagement and students' autonomous learning were improved from $60 \%$ on the first half semester to $87 \%$ on the second half semester or after the implementation of portfolios assessment.

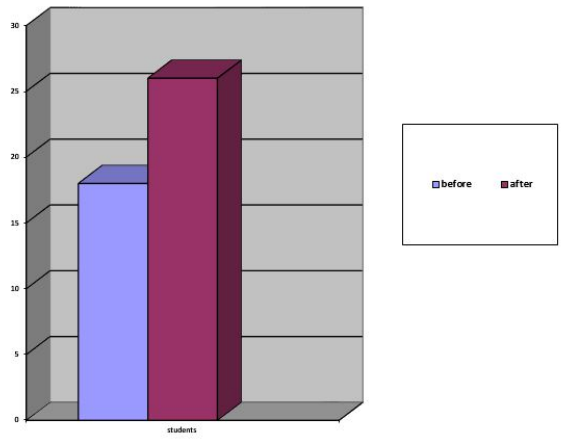

FIGURE 3 | The Improvement Result from Observation Checklist

It was found from observation checklist that twenty-six (26) students out of thirty (30) students complete all the activities during the research. Only four (4) students could not complete the process of portfolio assessment, two (2) students did not have individual consultation with the lecturer in organizing ideas, one (1) students did not do both peer-review and selfassessment to revise and edit their draft, and one (1) students did not join writing conference.

The result of observation checklist is in line with the result of students' interview, it was found that most of the students agree that 'clearly stated criteria' in judging their process and product writing can motivate them to complete portfolio assessment in order to get good score in essay writing class. This result support the result of some previous studies conducted by Khonbi and Sadeghi (2012); Romova and Andrew (2011), They found that the implementation of portfolio assessment can encourage the students to set goals in improving their writing competence and performance. In addition, this research result also showed that students can also be more aware of their weakness in writing by providing them scoring rubric used to assess their final draft. As stated by Nicolaidou (2013); Sundeen (2014); Wang (2014); Tyas (2012) scoring rubric can provide students insightful ideas of specific criteria of what is expected from the lecturer of their writing product. It also motives the students to be an autonomous learner since it let students practice to evaluate their own writing in order to know their own strength and weakness.

These research findings indicate that writing should not be seen as an activity to produce a product by neglecting the process to reach the goals. Rather, it should be seen as a recursive process in composing a piece of written text for certain objective, reader, and language use (Widodo, 2008). Further, the use of portfolio assessment in this Essay Writing class can be considered as a good strategy to make students become more independent learners and self-confident since they become more aware of their own strength and weakness (O'malley and Pierce, 1996; Ilke Büyükduman and Şirin, 2010). 


\begin{tabular}{|c|c|c|c|}
\hline Meeting & Stage & Students' Activities & Text Type \\
\hline Meeting 9 & $\begin{array}{l}\text { Introduction to PA } \\
\text { Planning }\end{array}$ & $\begin{array}{l}\text { Understanding the concept of PA } \\
\text { Discussing the criteria used to evaluate their PA } \\
\text { Generating ideas (brainstorming/clustering) } \\
\text { Organizing ideas (outlining) } \\
\text { Face to Face outline consultation with lecturer (inside/outside the class hour) }\end{array}$ & \multirow{4}{*}{$\begin{array}{l}\text { Cause-effect } \\
\text { (Individual work since } \\
\text { at the first half } \\
\text { semester the students } \\
\text { developed Cause- } \\
\text { effect essay in group) }\end{array}$} \\
\hline Meeting 10 & Drafting & $\begin{array}{l}\text { Find some references related to the students' topic } \\
\text { Paraphrasing the ideas from the references } \\
\text { Developing Draft } 1\end{array}$ & \\
\hline Meeting 11 & $\begin{array}{l}\text { Revising \& Editing: } \\
\text { Peer review } \\
\text { Drafting }\end{array}$ & $\begin{array}{l}\text { Use "Essay Checklist (Revising)" and Essay Checklist (Editing)" (see Appendix) } \\
\text { as a guide to give comment and suggestion } \\
\text { Developing Draft 2/Final Draft }\end{array}$ & \\
\hline Meeting 12 & $\begin{array}{l}\text { Assessing } \\
\text { Writing Conference } \\
\text { - Post Writing } \\
\text { - Reflection }\end{array}$ & $\begin{array}{l}\text { (done by the lecturer outside the class hour) } \\
\text { Discussion: } \\
\text { Give comments and suggestions on their friend's essay shown on the screen }\end{array}$ & \\
\hline Meeting 13 & $\begin{array}{l}\text { Model Text } \\
\text { Planning }\end{array}$ & $\begin{array}{l}\text { Read model text and answering some comprehension question related to the text } \\
\text { Identifying the generic structure of Problem-Solution essay } \\
\text { Generating ideas (brainstorming/clustering) } \\
\text { Organizing ideas (outlining) } \\
\text { Face to Face outline consultation with lecturer (inside/outside the class hour) }\end{array}$ & \multirow{4}{*}{$\begin{array}{l}\text { Problem-Solution } \\
\text { (Group work) }\end{array}$} \\
\hline Meeting 14 & $\begin{array}{l}\text { Drafting } \\
\text { Revising \& Editing: } \\
\text { Pcer review } \\
\text { Drafting }\end{array}$ & $\begin{array}{l}\text { Find some references related to the students' topic and Paraphrasing the ideas } \\
\text { from the references. Then, developing Draft } 1 \text { (outside the class hour before the } \\
\text { class begin) } \\
\text { Use "Essay Checklist (Revising)" and Essay Checklist (Editing)" (see Appendix) } \\
\text { as a guide to give comments and suggestions on other group's work } \\
\text { Developing Draft 2/Final Draft }\end{array}$ & \\
\hline Meeting 15 & $\begin{array}{l}\text { Assessing } \\
\text { Writing Conference } \\
\text { - Post Writing } \\
\text { - Reflection } \\
\end{array}$ & $\begin{array}{l}\text { (done by the lecturer outside the class hour) } \\
\text { Discussion: } \\
\text { Give comments and suggestions on their friend's essay shown on the screen }\end{array}$ & \\
\hline Meeting 16 & Final Exam & Submission of students work from meeting 9-15 & \\
\hline
\end{tabular}

FIGURE 2 | The Implementation of Portfolio Assessment

TABLE 1 | Observation checklist for portfolio assessment adapted from Emaliana et al. (2019)

$\begin{array}{ll}\text { Students' name: } & \text { Check }(\sqrt{ }) \\ \text { Text type: } & \\ \text { Date: } & \\ \text { Generating ideas: use clustering/brainstorming/free writing } & \\ \text { Organizing ideas: use outlining/tree diagram } & \ldots \ldots \\ \text { 1. Consultation with lecturer } & \ldots \ldots \\ \text { 2. Consultation with lecturer } & \ldots \ldots \\ \text { 3. Consultation with lecturer } & \ldots \ldots \\ \text { Drafting: } & \\ \text { Draft 1 } & \ldots \ldots \\ \text { Draft 2 } & \ldots \ldots \\ \text { Draft } 3 & \ldots \ldots \\ \text { Final Draft } & \ldots \ldots\end{array}$

Revising: focus on the content and organization Peer review / self-assessment

Editing: focus on grammar, vocabulary, and mechanics (format, punctuation, ...... spelling, and capitalization) Peer review / self-assessment

Writing conference 


\section{CONCLUSION}

The result of the study proved that portfolio assessment can promote students' autonomous learning since it provides some benefits for students such as provide a guide for self-evaluation, reflection, and peer review. However, time limitation need to be considered for further researcher since it becomes the only problem faced by the researcher in conducting this research. The researcher spent more time outside class hour to do writing conference with the students because the Essay Writing course only has 2 credits (100 minutes for each meeting). Face to face writing conference for each student spent about 10-15 minutes. Therefore, it is recommended for future researchers, teachers, or English lecturers to combine portfolio assessment with online platform to minimize the problem in this current

\section{APPENDIX}

\section{Semi-structured Interview Guide}

1. Completing portfolio assessments was useful for improving writing skills.

2. Completing portfolio assessments was useful for writing better essays.

3. Completing portfolio assessments encourages students to improve their own essays.

4. Completing portfolio assessments encourages students to organize their own essay better.

5. Portfolio assessment makes students want to complete the essay on time.

6. Portfolio assessment makes students feel responsible for their own learning.

7. Portfolio assessment helps students learn in and out of classroom.

8. Portfolio assessment helps students to be more aware of their strengths and weaknesses.

9. Portfolio assessment requires students to find their own resources.

10. Writing conference with lecturer helps students to improve the content of their writing.

11. Peer review session encourages students to revise their own draft.

12. Peer review session encourages students to give comment and suggestion on their peer's work.

13. Students prefer Portfolio Assessment rather than traditional assessment.

\section{Essay Checklist (Revising)}

Use the Essay checklist (Figure 4) as a guide to review the organization of your essay. Check off the items that are true. If any of the items are not checked off, correct your essay on the second draft. study. All in all, the implementation of portfolio assessment in essay writing classroom can be used as a mean to improve students' competence in developing and organizing their writing. It also encourages students to strengthen their self-confidence and give focus both on the process and product.

\section{ACKNOWLEDGEMENT}

The writer would like to say thank you to all the participant of this research who work hard in completing the portfolio assessment. The writer also would like to show her gratitude to the reviewer for the very valuable comments for the improvement of the manuscript.

\begin{tabular}{|c|c|c|}
\hline Descriptions & Check (V) & Comment \\
\hline The essay is a problem-solution essay & & \\
\hline Use appropriate structure, either block or chain & & \\
\hline The thesis statement is clear and strong & & \\
\hline There are 3 body paragraphs & & \\
\hline Each body paragraph has clear topic sentence & & \\
\hline $\begin{array}{l}\text { The first body paragraph is supported by facts, } \\
\text { reasons, example, references, etc. }\end{array}$ & & \\
\hline $\begin{array}{l}\text { The second body paragraph is supported by facts, } \\
\text { reasons, example, references, etc. }\end{array}$ & & \\
\hline $\begin{array}{l}\text { The third body paragraph is supported by facts, } \\
\text { reasons, example, references, etc. }\end{array}$ & & \\
\hline $\begin{array}{l}\text { The conclusion summarizes or paraphrase the main } \\
\text { point of each body paragraph }\end{array}$ & & \\
\hline
\end{tabular}

FIGURE 4 | Checklist for Revising Step

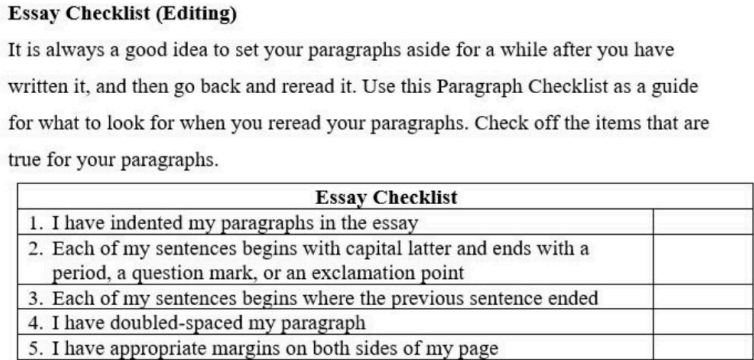

If any of the items are not checked off, correct your essay on the second draft.

\section{Essay Checklist (Editing)}

It is always a good idea to set your paragraphs aside for a while after you have written it, and then go back and reread it. Use 
the Paragraph Checklist (Figure 5 ) as a guide for what to look for when you reread your paragraphs. Check off the items that are true for your paragraphs. If any of the items are not checked off, correct your essay on the second draft.

\section{REFERENCES}

Aydin, S. (2010). EFL writers' perceptions of portfolio keeping. Assessing Writing, 15(3):194-203.

Boardman, C. A. and Frydenberg, J. (2002). Writing to communicate: paragraphs and essays. New York. Pearson Education Inc.

Brown, H. (2007). Teaching by principles: An interactive approach to English pedagogy. Pearson Education ESL.

Ceylan, N. O. (2015). Fostering Learner Autonomy. Procedia-Social and Behavioral Sciences, 199:85-93.

Chan, V. (2003). Autonomous language learning: The teachers' perspectives. Teaching in Higher Education, 8(1):33-54.

Chang, C. C., Tseng, K. H., Liang, C., and Chen, T. Y. (2013). Using e-portfolios to facilitate university students' knowledge management performance: E-portfolio vs. non-portfolio. Computers \& Education, 69:216-224.

Emaliana, I., Tyas, P. A., Widyaningsih, G. E. N., and Khotimah, S. K. (2019). Evaluasi Pembelajaran Bahasa Asing pada Pendidikan Tinggi. Universitas Brawijaya Press.

Ilke Büyükduman, . and Şirin, S. (2010). Learning portfolio (LP) to enhance constructivism and student autonomy. Procedia - Social and Behavioral Sciences, 3:55-61.

Khonbi, Z. and Sadeghi, K. (2012). The Effect of Assessment Type (self vs. peer vs. teacher) on Iranian University EFL Students' Course Achievement. Language Testing in Asia, 2(4):47-47.

Lam, R. (2013). Two portfolio systems: EFL students' perceptions of writing ability, text improvement, and feedback. Assessing Writing, 132(153).

Nicolaidou, I. (2013). E-portfolios supporting primary students' writing performance and peer feedback. Computers \& Education, 68:404-415.

O'malley, J. and Pierce, L. (1996). Authentic Assessment for English Language Learners: Practical Approaches for Teacher. Addition-Wesley Publishing Company, Inc.

Railton, D. and Watson, P. (2005). Teaching autonomy: "Reading groups" and the development of autonomous learning practices. Active Learning in Higher Education, 6(3):182-193.

Richards, J. C. and Renandya, W. A. (2002). Methodology in Language Teaching: An Anthology of Current Practice. Cambrige University Press.

Romova, Z. and Andrew, M. (2011). Teaching and assessing academic writing via the portfolio: Benefits for learners of English as an additional language. Assessing Writing, 16(2):111-122.

Sundeen, T. H. (2014). Instructional rubrics: Effects of presentation options on writing quality. Assessing Writing, 21:74-88.

Tyas, P. (2012). The Effectiveness of Providing Students with a Scoring Guide in Teaching Writing. Unpubliashed Thesis.

Wang, W. (2014). Students' perceptions of rubric-referenced peer feedback on EFL writing: A longitudinal inquiry. Assessing Writing, 19:80-96.

Widodo, H. P. (2008). Process-based academic essay writing instruction in an EFL context. Jurnal Bahasa Dan Seni Tahun, pages 36-36.

Yastibas, A. E. and Yastibas, G. C. (2015). The Use of E-portfolio-based Assessment to Develop Students' Self-regulated Learning in English Language Teaching. Procedia - Social and Behavioral Sciences, 176:3-13.

Conflict of Interest Statement: The author declare that the research was conducted in the absence of any commercial or financial relationships that could be construed as a potential conflict of interest.

Copyright (C) 2020 Tyas. This is an open-access article distributed under the terms of the Creative Commons Attribution License (CC BY). The use, distribution or reproduction in other forums is permitted, provided the original author(s) and the copyright owner(s) are credited and that the original publication in this journal is cited, in accordance with accepted academic practice. No use, distribution or reproduction is permitted which does not comply with these terms. 